\title{
The Aspect of Social, Economic, Cultural and Public Health after Ten Years of Mining Closure Activities
}

\author{
D.Hartoyo \\ Doctoral Student at Environmental Science \\ University of Indonesia, \\ Jakarta, Indonesia \\ djokohartoyo@gmail.com
}

\author{
A. H. Soeparjo \\ Faculty of Natural Science \\ University of Indonesia, \\ Jakarta, Indonesia
}

\author{
A. T. Alamsyah \\ Faculty of Technic \\ University of Indonesia, \\ Jakarta, Indonesia \\ A.Herlambang \\ Center of Environmental Technology \\ Agency for the Assessment and Application of Technology, \\ Jakarta, Indonesia
}

\begin{abstract}
Buyat Bay is a small bay located Minahasa, North Sulawesi, Indonesia. The bay was famous due to the mining activities of Newmont Minahasa Raya Ltd (NMR) since 1996, where NMR utilizes this bay as the flow of the disposal of tailings (mining waste) for its gold mining activity. The aim of this study is to know clearly the result of the gold mining activities, since the closure of the NMR. Studies have been conducted for $\mathbf{1 0}$ years to the impacts caused by the gold mining activities in Buyat Bay. The purpose of the survey of the social, economic, cultural and public health is to know the public perception by spreading questionnaire to residents who reside around Buyat Bay.

The socio-cultural and emotional bond people in Buyat Bay are still very strong. The communities around Buyat Bay area very much agree with the monitoring of Buyat Bay. People around Buyat Bay has the aspect of good health as evidenced by building walls, floor and roof are already fairly good for health. Indeed, there are still some that did not meet health, this is because their earnings slightly.

The pollution issue was arised in the media, causing the onset of diseases like Minamata evidently was not true. It can be seen that the environment and waters of Buyat Bay is getting better.
\end{abstract}

Keywords-Buyat Bay; social; economic; public health.

\section{INTRODUCTION}

Buyat Bay is a small bay located on the south coast of the peninsula Minahasa, North Sulawesi, Indonesia. Administratively, the bay is in Southeast Minahasa Regency. [1] The bay was famous due to the mining activities of Newmont Minahasa Raya Ltd (NMR) since 1996, where Newmont Mining Corporation under its subsidiary NMR utilize this bay as the flow of the disposal of tailings (mining waste) for its gold mining activity after going through the process or treatment. [3][5][6][7][8] Disposal of tailings on the seabed (Sub Marine Disposal) in Buyat Bay safely predicted from dispersion to water turns an impact on the marine environment and ecosystems, due to the influence of ocean dynamics of the existence of these tailings. Seabed conditions are ideal as a tailings disposal and landfilling is the deep sea that are not affected by the dynamics of the ocean and isolated, hence that the tailings do not have an impact on the ecosystem.

When viewed economically, the presence of NMR has helped many people around Buyat in every way and can be seen in the area of economic growth increased rapidly, it does the number of residents increased by increments of migrants from various regions of Sulawesi and others to work in companies NMR.

Indication of the rapid growth of population in Buyat Bay along the Southeast Minahasa Regency in various villages and districts of Ratatotok from west to east at has a variety of great impact on the social, economic, cultural and public health in the district of Ratatotok. Various problems arise both from the public and the environment of Buyat Bay.

In 2004, there were health case unusual is known as the case of Minamata and many people experience itching all over his body caused by the quality of the water has been polluted due to discharge of tailings hail cleaning process gold ore directly into water bodies or to sea without prior treatment. It is then raised by environmentalists (NGO) that leads to the suspicion that NMR violate regulations disposal of mining waste levels above permissible that pollute the environment and in particular the waters of Buyat Bay. WALHI, the 
Indonesian environmental activist, claiming Newmont stockpiled 2,000 tons of tailings into the bay every day.

The case was then stuck in the 2004's along with the endless production of gold and NMR had to undergo several trials to prove whether this company had polluted the waters of Buyat Bay and the end of this trial was the closure of operations of NMR.

[2] Post-closing of NMR since 10 years ago, the company is required to monitor the development of environmental conditions especially water in Buyat Bay which aims to determine how far the environmental conditions and the waters of Buyat Bay after left by NMR, is getting worse or vice versa is getting better. Similarly, the changes that occur in society in terms of social, economic, culture and health. The case continues until the year 2013 and of the results of the monitoring can be concluded that there were no environmental pollution and waters of Buyat Bay by NMR and indicated that pollution that occurred due to the practice of illegal mining by residents or migrants who do not process waste leaching of gold ore directly to the waters.

\section{METHODS}

\section{A. Objective and Targets}

The purpose of the survey of the social, economic, cultural and public health is to know the public perception of the post-10-year closure of mining activities of NMR in Buyat Bay District of Ratatotok, Southeast Minahasa Regency.

The objective of this activity is the public informed of the plans, objectives and benefits of the NMR post-closure plan. Surrounding people are expected to support the plan of government activities in the future on the management of Buyat Bay.

\section{B. Survey and Distribution of Questionnaire}

To know clearly the result of the gold mining activities, since the closure of the NMR activities studies have been conducted for 10 years to the impacts caused by the gold mining activities in Buyat Bay. [2][4]Monitoring activities have been conducted on the environmental conditions and water quality in Buyat Bay. Similarly, the aspect of social, economic, cultural and health of the people around Buyat Bay. Socio-Economic condition monitoring is done by spreading questionnaire to residents who reside around Buyat Bay. Questionnaires were distributed to as many as 53 respondents representing the population and randomly distributed in several places of the resident in Ratatotok Village, where the village is located along the Buyat Bay. The number of variables in the questionnaire are 43 variables and is divided into several sections, namely: Identity Respondents, Economic Social and Cultural (Cultural Social and Public Perception), and Public Health.

\section{ANALYSIS AND DISCUSSION}

The questionnaire was made mostly with closed questions (closed-ended questions) and small open questions. Measurement scale used is the scale nominal and ordinal scale. The questionnaire contains 43 (forty- three) questions the grouping as follows: The identity of the respondent, public perception of the quality of Buyat Bay, meeting the needs of clean water and sanitation systems, public perception of coastal management program at Buyat, The system of institutional and community participation.

The survey results have been obtained using the data tabulation of data processing with SPSS (Statistical Product and Service Solution) Ver. 21.

\section{A. Identity of Respondents}

In the distribution of questionnaires to the respondents is not determined to be male or female. From the survey, found that the number of men $(68 \%)$ more than women (32\%).

For the age of the respondents ranged from 23 years to 60 years. Therefore in determining the group then divided into 4 sections or boundaries between the age of the age group 21-30 (15\%), 31-40 (42\%), 41-50 (34\%), 51-60 $(9 \%)$.

Most respondents had already lived in Buyat more than 5 years and already an adult and already married, so that in answering the questions in the questionnaire may be justified. Respondents who have over 5 years living in Buyat Bay by $98.1 \%$ occupy the home or residence with self-owned $(94.3 \%)$. They know once the condition of Buyat Bay from beginning until companies NMR left Buyat Bay.

Muslim majority of respondents (73.6\%) and Protestants (26.4\%). Position in the community are ordinary people with the highest education level is elementary school (39.6\%) and junior (34\%) and high school $(26.4 \%)$. It can be assumed that the level of education in Buyat Bay is largely lacking and in particular to the respondents is very less. This is due to the majority of respondents in their everyday fishermen with a value of $67.9 \%$ and the remainder as employees $(15.1 \%)$, farmers $(1.9 \%)$, labor $(9.4 \%)$, own businesses $(1.9 \%)$, and services / drivers (3.8\%). The fishermen work has been passed down from parents and families with income that is not fixed and the highest is between Rp. 1,500,000 - Rp. $2,000,000(62.3 \%)$. However, this income is very little when compared with the costs they incur for the survival of between Rp. 750,000 - Rp. 1,500,000, it can be concluded that the revenue and expenditure of the respondents as fishermen are very less.

\section{B. Economic Social and Cultural Rights}

This section discusses the socio-economic and cultural conditions of the people residing in Buyat Bay, chiefly social and cultural issues. At the time the company of NMR still operates in Buyat Bay, many immigrants from different regions who try their luck in this area by becoming employees of NMR or trade and cooperation with the indigenous people of Buyat Bay. With the newcomers, the possibility of intermingling between the natives and the migrants might happen. But it is not just assimilation, the possibility of dispute could occur which could cause in many ways. These possibilities will be discussed in this section.

Residents of Buyat Bay since long time have the shape of activities that continue to be made either routine or religious events or worship. In the routine, many people 
still do the activities undertaken by women gathering $(52.8 \%)$, the activities of worship $(26.4 \%)$ and teaching $(9.4 \%)$ and the remaining other activities. Again different religion is not a barrier in doing activities together. Here we can see that although the majority of the Islamic religion, but not as a barrier in joint activities with other residents or immigrants of different religions. Cultural activities are still carried out, namely religious celebrations $(81.1 \%)$. From interviews with respondents, religious activities are often carried ie one week after the Eid al-Fitr or Eid known as 'Ketupatan'. All citizens together contribute food to be eaten with all the residents in the neighborhood and not the exception of other faiths. Similarly, in another case that is traditional marriage ceremonies, community mutual aid (11.3\%). In addition to traditional activities, other activities are often carried out as voluntary work or activities of mutual cooperation by local residents. This shows that the people of Buyat Bay have a very close emotional relationship. Not just a fun activity, but other activities are activities that are closely procession of death $(9.4 \%)$. All residents in the neighborhood intervened mutual help in organizing the funeral ceremonies.

In connection with the Buyat Bay native settlers does not seem problematic. It looks mutual voluntary work or mutual aid together in their neighborhoods $(75.5 \%)$. To the Islamic religion, often carried out teaching activities $(5.7 \%)$, similarly, in the activities of mutual help is in case of death $(5.7 \%)$.

Familiarity or good relations between natives and immigrants due to intermingling among them and they do not discriminate or keep a distance from one another. This blurring can occur in many ways and the most common is mixing in the form of marriages between natives and the migrants $(64.2 \%)$, then kinship in helping various terms $(18.8 \%)$ as well as the cooperation of business / trade (17 $\%)$.

In social life, discord is a natural thing. Similarly, the people of Buyat Bay might have been a dispute between local people and migrants. But the results of the questionnaire showed that stating once and never disputes have the same value that is $43.3 \%$ and the remaining states do not know (13.2\%). In this case ignorance of respondents can be interpreted together with never a dispute. So this shows that never happened dispute is $56.5 \%$.

In case of dispute, the biggest problem is a land acquisition $(24.5 \%)$ and the second largest is overlapping land ownership (9.4\%). While other issues equally with relatively small value. Buyat Bay community is still strong with customary manners. This can be seen when there is a dispute, and then they will conduct consultations with the authorities or to delegate to the traditional leaders to solve these problems. It appears that the bonds between the population very closely and people are still holding tightly the local customs through traditional head.

Overall it can be concluded that the socio-cultural and emotional bond people in Buyat Bay is still very strong. This can be seen with the familiarity between the natives and the migrants in various things and they still respect the local customs, namely the completion of all things through elders or traditional leaders

\section{Public Perception}

At the time of NMR still operating in the Buyat Bay gold mine excavation effort, a lot of information stating that the company had polluted environment and waters in Buyat Bay, in the end the company was closed. With the departure of Buyat Bay NMR company which has been running for approximately 10 years, it is necessary need to know how far the public perception of the environment and waters of Buyat Bay, whether the pollution issue in Buyat Bay in advance to make the condition gets worse or getting better.

To determine the extent of the changes that occurred in Buyat bay over the last 10 years, it is necessary to interview directly to the people who reside in the area of Buyat Bay. From the results of the questionnaire, obtained information that the communities around Buyat Bay know exactly the condition of Buyat Bay (69.8\%) and they get information about the condition of Buyat Bay from neighbors or communities around Buyat Bay (35\%). Information obtained through informal meetings between the communities or from officials / village officials who regularly met local residents to exchange information $(5 \%)$.

Overall, communities around Buyat Bay area very much agree with the monitoring of Buyat Bay (98.1\%). This shows that people are eager to know the real condition of the environment and waters of Buyat Bay after being abandoned by NMR 10 years ago. In addition, the monitoring results to increase their knowledge about the waters of Buyat Bay where such information can be used for life and work, mostly fishermen. With the information that the waters of Buyat Bay is polluted with waste tailings disposal proceeds from NMR, it is feared that such waste also pollute water sources are commonly used by residents for their daily lives. Communities around Buyat Bay are still many who rely on the source of their water from wells although there is also a gain of tap water. The water they use an average of the wells was brackish because of its location close to the sea so that seawater intrusion affects the quality of water on land. The water is usually used for bathing, washing and toilet, while for cooking and drinking normally they buy or use tap water.

Most people already have water wells, where respondents who have wells as much as $79.2 \%$ while the remaining $20.8 \%$ do not have piped water wells and use tap water. In more detail the problem of water needs to be discussed at the Public Health.

Monitoring conducted after the closing of NMR, will be seen to what extent the impact that occurred in Buyat Bay community and the environment as well as the waters of Buyat Bay. When viewed from the questionnaire, it turns out after the closing of NMR showed significant changes in the condition of Buyat Bay waters which are getting better $(92.5 \%)$. This shows that the waters of Buyat Bay are getting better due to the reduction of waste into waterways. But whether the incoming waste into Buyat Bay waters coming from the exhaust tailing NMR or from illegal excavations that much going on around Buyat Bay.

Based on information from the respondents, until recently illegal excavation is still ongoing and disposed waste cannot be controlled. People agreed with 
monitoring that it can be known the Buyat Bay pollution that occurs at this time due to what. Besides the monitoring results can also be used as a reference by the public on the condition of Buyat Bay development $(37.7 \%)$ as well as add knowledge of Buyat Bay neighborhood conditions (39.6\%). Facilities and infrastructure for the community turns out there is a change after being abandoned by NMR, especially for the improvement of rural infrastructure (69.8\%) and general social development $(18.9 \%)$. Costs incurred in the repair and construction of infrastructure facilities were provided by NMR. The economic condition of society has declined and revenue (income) communities declined considerably. To find out more detail to how big the downturn, should do more in-depth study of the economic problem of society in particular.

\section{Public Health}

Public health cannot be separated from the monitoring associated with the environment and waters of Buyat Bay, because a lot of things related to health and lifestyle of the people. For example to clean water which is used for cooking, drinking, bathing, washing if it is polluted or not polluted. Similarly, with their regular garbage problem waste, whether carelessly or coordinated.

Problems housing conditions also affect public health. If we look at the condition of residential communities around Buyat Bay, then not all the conditions of their homes qualify as healthy house so there are still many shortcomings. It still needs to be improved. This relates to the income of the society where most are fishermen with a mediocre income.

From the survey results shows that most public housing is made of walls $(60.4 \%)$, then from the board / wood $(26.4 \%)$, half-timber walls $(9.4 \%)$ and from woven bamboo $(3.8 \%)$. It appears that there are houses made of woven bamboo small percentage and they are usually located on the coast, while those made from the wall are located somewhat in city.

The floor of the public house mostly made of plaster cement $(47.2 \%)$, tiles $(28.3 \%)$ and ceramics $(17 \%)$, there was even made of the soil $(1.9 \%)$ and wood $(5.7 \%)$. For wood floors, usually in the form of houses on stilts those are still many in Buyat Bay. From these data it can be concluded that the majority of people are already aware of the importance of good and healthy home. Similarly to the roof of the house, the biggest made of zinc (88.7\%) and then of thatch $(9.4 \%)$ and asbestos $(1.9 \%)$.

Overall for a residence or home, the communities around Buyat Bay has the aspect of good health as evidenced by building walls, floor and roof are already fairly good for health. Indeed, there are still some that did not meet health, this is because their earnings slightly.

As discussed above, water is one of the sources for the life of the community. Especially for the communities around Buyat Bay, the water is good for health including somewhat difficult to obtain because of the position which is not far from the sea so that the intrusion of seawater has a major effect which causes the water becomes brackish taste. For people who live a bit away from the coast or the center of activity, already use tap water for cooking $(49.1 \%)$ and for sewage $(32.1 \%)$. But there are those who use the water wells for cooking
(30.2\%) but the biggest for 'bath-wash-toilet' (47.2\%). As for the people who live in coastal areas, more use of water from wells drilled (11\%) for cooking and for 'bathwash-toilet' (11.3\%). Difficult to get tap water or wells / drill prefer to buy from water vendors or protected springs and rivers. It is used for sewage water obtained from wells or boreholes with a depth not too deep, only about 2-4 $\mathrm{m}(35.8 \%)$ and 4-6 $\mathrm{m}(20.8 \%)$. Nothing has wells $<2 \mathrm{~m}$, this means that when the dry season, wells will be dry. From discussions with respondents, the water they use mainly for toilets. It is evident that they never feel itchy or other diseases and means that the water is not polluted as ever on the issue.

A healthy home is a home that is equipped with latrines and septic tanks. It has a big impact on health due to the source of the disease comes from the dirt. From the survey results showed that the house is equipped with a toilet with a septic tank at $75.5 \%$, which means that the community is aware of health and hygiene. Indeed, there are those who do defecate in the river $(9.4 \%)$ or in the pond $(3.8 \%)$ and public toilets $(7.5 \%)$. From this data it can be concluded that most people are already aware of health. In addition, the traditional chief or village officials must often complete socialization of the importance of latrines with septic tanks to health.

Talking about toilets, it cannot be separated from liquid waste discharged from cleaning the toilets. It is necessary to note Wastewater Disposal System (WDS) of residence community is already equipped or not. From the survey results showed that most people already have a building equipped with waste water reservoirs $(58.5 \%)$, through gutter $(32.1 \%)$, the channel to the yard $(1.9 \%)$ and the channel to the river $(7.5 \%)$. When viewed from the health and WDS are correct, they should not waste water discharged into the yard or into water bodies. This will greatly pollute mainly directly discharged into the river. It is still done by the people due to lack of information or information problems of WDS and also because of the lack of land as the location of the waste water reservoir.

The waste problem is also important as well as waste water because the waste is also a source of disease. Handling and good waste management does require a huge cost, but it could be a little but there is awareness of the community to handle it together. A healthy home should be equipped with a landfill, but not all can provide due to hit land there. From the survey results, the Buyat Bay communities dispose of waste in a manner inserted into a plastic bag $(56.6 \%)$ or collected into cans / bins $(20.8 \%)$ and made trash by digging holes in the yard $(22.6 \%)$. Usually from the local village board there that take from house to house and then dumped into landfill $(49.1 \%)$. In addition there are burnt $(45.3 \%)$ but it is advised not to do because the smoke of burning very distracting environment and those who have respiratory disease would be very disturbing. Indeed, there are those who throw garbage into the river $(1.9 \%)$ but it is very small and this is the task of village officials to notify a result of these actions.

Buyat community in general can maintain their own health is well proven with a disease that is often suffered by the largest community of Buyat Bay is cough (77.4\%). This is evidenced by the low percentage rate of other 
diseases that attack the Buyat society. Issue stating that in Buyat Bay never infected hives as Minamata caused contamination in Buyat Bay waters, it is not true because the disease is relatively small $(5.7 \%)$. The second highest was asthma (7.5\%). Asthma can be caused by the default of a family or environmental conditions that are not clean, especially the air. But when viewed from the environmental conditions, it is highly unlikely that the air pollution in Buyat Bay. It can be concluded that asthma suffered by the respondent is inherited from family.

\section{CONCLUSIONS}

Strata respondents consisted of public figures, ordinary people and people around the coastal waters of Buyat Bay from east to west in the District Ratatotok, District and Sub-District Kotabunan Belano and 9 Village / Village. Generally, people around the coastal waters of Buyat Bay concerned or very concerned about the condition of Buyat Bay waters because most of the community is the District Ratatotok Fisherman. Even in some villages have formed groups of environmentalists, who clearly had a stake and a considerable role for the maintenance or conservation of coastal Buyat Bay. The carrying capacity of Buyat Bay can be maintained or even improved.

The District community Ratatotok know and declare that the conditions of the waters of Buyat Bay is still within reasonable limits. Because of their helplessness in terms of quality of human resources, funding issues and still less intensive coordination with government and private institutions, the majority of people living in around the waters of Buyat Bay cannot do much to tackle environmental problems that are directly related to social, economic, cultural and public health.

Generally, people around the coastal waters of Buyat Bay strongly supports the existence of NMR to exist in Sub Ratatotok, because during the closure of NMR very considered burdensome life of the local community, especially in terms of economic needs of diminishing. Although, only a small fraction that can meet their needs economically well.

Habits and culture around the coastal waters of Buyat Bay is still showing on the condition that it accepts the state of the situation and often recur despite its negative effects are perceived detrimental to society itself. This situation reveals the passive role of the community.

The benefits desired by the community will be the implementation of water quality monitoring technology i.e information about pollution (water quality) and management plans and the development of Buyat Bay.
Furthermore the hopes is the possibility that the ease of obtaining information and knowledge on disaster prevention, and environmental pollution that endanger water.

The pollution which has raised up in the media that cause diseases like Minamata was not true. It can be seen that the environment and waters of Buyat Bay is getting better and the results are very good fishing.

Public health related skin diseases caused by contaminated water, is not true. Since water is consumed by people who obtained from wells or boreholes are still good and not polluted.

\section{ACKNOWLEDGMENT}

Thanks to Dr. Deni Nugroho which has facilitated the socio-economic survey in the monitoring program. Hendra and Bono have helped as surveyor.

\section{REFERENCES}

[1] Ministry Of Environment. Report on Handling research suspected cases of pollution and / or destruction of the environment in Buyat Village Beach and Village East Ratatotok. Ratatotok District of South Minahasa district, North Sulawesi.

[2] Edinger, Siregar \& Blackwood. W. Heavy metal contamination of shallow marine sediments from submarine tailings disposal and artisanal gold mining, Buyat-Ratatotok district, North Sulawesi, Indonesia. 2007; 40: 404-425.

[3] Poling, G. An introduction to deep sea tailing placement. In G.E. Poling (Ed), Underwater tailing placement at Island Copper mine: A success story (pp. 1-16). Littleton, Colorado: Society for Mining, Metallurgy, and Exploration. 2002.

[4] Prisetiahadi, K., \& Yanagi, T. 2008. Seasonal variation in the behavior of tailing wastes in Buyat Bay, Indonesia. Marine Pollution Bulletin, 170-181.

[5] Ellis, D., \& Ellis, K. Very deep STD. Marine Pollution Bulletin 1994; 472-476.

[6] Jones, S.G, \& Ellis, D.V. Deep water STD at the misma gold and silver mine, Papua New Guinea. Marine Georesoures \& Geotechnology 1995; 13: 1553-1562.

[7] Poling, G. An introduction to deep sea tailing placement. In G.E. Poling (Ed), Underwater tailing placement at Island Copper mine: A success story (pp. 1-16). Littleton, Colorado: Society for Mining, Metallurgy, and Exploration. 2002.

[8] Ellis, D.V. The role of deep submarine tailing placement in the mitigation of marine pollution for coastal and island Mines. In T. Hover. Nova Science Publisher. 2008. 